ПСИХОЛОГО-ПЕДАГОГІЧНІ ОСОБЛИВОСТІ ДИСТАНЦІЙНОГО НАВЧАННЯ ІНОЗЕМНОЇ МОВИ У ВНЗ

\title{
PSYCHOLOGICAL AND PEDAGOGICAL ASPECTS OF FOREIGN LANGUAGE DISTANCE LEARNING IN HIGHER EDUCATION INSTITUTIONS
}

Статтю присвячено вивченню психологопедагогічних особливостей дистаниійного навчання іноземної мови у вищих навчальних закладах. Визначено переваги та недоліки застосування дистанційних освітніх технологій порівняно із традиційними методами іншомовного навчання. Визначено, що крім ефективної організації навчання $і$ методичної якості навчальних матеріалів, які використовуються у дистаниійному курсі, великого значення набуває вивчення фракторів, які підвищують успішність навчання будь-якої групи та окремого студента з урахуванням психологічних особливостей студентів, насамперед когнітивних стилів. Зазначено, що врахування особливостей когнітивних стилів студентів під час засвоєння іноземної мови передбачає (разом із іншими компонентами) використання індивідуалізованих методів, засобів і технологій дистанційного навчання.

Дистанційні освітні технології припускають розроблення індивідуальних навчальних програм, які враховують специфріку дистанційного навчання іноземної мови. Визначено, що однією з індивідуальних навчальних програм, які враховують специфріку дистанційного навчання, $\epsilon$ навчальне комп'ютерне завдання, що розглядають як один із основних засобів ефективної організації самостійної роботи студента, який, у свою чергу, дозволяє забезпечити інтерактивність навчання іноземної мови.

у висновках статmі зазначено, що дистанційне навчання сприяє втіленню сучасної освітньої парадигми, невід'ємними компонентами якої є особистісно орієнтоване навчання, індивідуалізація і диференціація навчальної діяльності, можливість автономного навчання, самоосвіта $і$ саморозвиток студентів. Дистанційне навчання також є мотивуючим фрактором вивчення іноземних мов, оскільки сприяє не тільки формуванню загальнокультурних $і$ професійних компетениій студентів, але й іншомовної комунікативної компетенції. Усі чі чинники зумовлюють необхідність розроблення сучасних програм розвитку лінгвістичної освіти, а також моделі дистанційного навчання, зокрема з іноземних мов, з урахуванням педагогічних позицій і соціокультурних, культурологічних, психологічних особливостей студентів.

Ключові слова: психолого-педагогічні особливості, дистанційні освітні техно- логії, навчання іноземної мови, вищий навчальній заклад, інтерактивна взаємодія, педагогічний супровід.

The article is devoted to the study of psychological and pedagogical features of a foreign language distance learning in higher education institutions. The advantages and disadvantages of distance learning technologies in comparison with traditional methods of foreign language teaching have been determined. It is revealed that in addition to effective training and methodological quality of educational materials used in a distance learning course, the study of factors, increasing the success of any group and individual student considering the psychological characteristics of students (particularly all cognitive styles) becomes of great importance. It is noted that considering the peculiarities of students' cognitive styles in the process a foreign language mastering provides (with all the other components) the use of individualized methods, tools, and distance learning technologies.

Distance learning technologies involve the development of individual training programs, considering the specifics of a foreign language distance learning. It was found that one of the individual educational programs, related to specific distance learning, is a training computer task, which is considered as one of the main tools to effectively organize students' independent work, in turn allows teachers to provide interactive learning of a foreign language.

The article concluded that distance learning contributes to the realization of the modern educational paradigm, the key components of which are personality-centered learning individualization and differentiation of educational activities, the possibility of students' autonomy, self-education and self-development. Distance learning is also a motivating factor in foreign languages learning, as it not only advances the development of general cultural and professional competencies of students, but also foreign language communicative competence. All these factors contribute to design modern programs for the linguistic education development, as well as the model of distance learning, in particular, foreign languages from the pedagogical point of view and considering the socio-cultural, cultural and psychological characteristics of students. Key words: psychological and pedagogical aspects, distance learning technologies, foreign language teaching, interactive interaction, pedagogical support. аграрного університету

Розвиток сучасних цифрових технологій зумовлює підвищення доступності якісної вищої освіти, що призводить до поетапного впровадження технологій дистанційного навчання як на різних рівнях освіти, так і за різними напрямками підготовки і спеціальностями у межах вищої освіти. Слід відзначити, що дистанційне навчання іноземної мови у закладах вищої освіти моделюється відповідно до цілей, завдань і змісту очного навчання, оскільки визначається стандартами і здійснюється у контексті освітніх програм для очного навчання. Принципова відмінність дистанційного навчання від очного насамперед полягає у формі презентації навчального матеріалу, засобах взаємодії педагога 
і студента. Форма презентації обумовлюється специфрікою дистанційного навчання, можливостями інформаційного середовища.

Нині дистанційні технології відіграють ключову роль у підвищенні якості навчання іноземним мовам у вищій школі. В усьому світі розробляють велику кількість комп'ютерних програм для самостійного вивчення іноземної мови, накопичено чималий досвід створення тестових завдань в онлайн-режимі, створюється багато тематичних і спеціалізованих порталів і сайтів. Із кожним днем збільшується їх кількість і підвищується якість. Проте, як свідчать проведені дослідження, у цих розробках не повно враховуються психологічні і психолого-педагогічні особливості моделювання і впровадження таких систем; поняття «інфрормаційне та комунікаційне комп'ютерне освітнє середовище» ще не набуло належного розгляду із психологічних позицій; дидактичні та методичні питання дистанційної освіти не мають донині належного психологічного обґрунтування. Особливо гостро вищезазначена проблема постала під час дистанційного навчання у період пандемії коронавірусу - COVID-19, коли з'ясувалося, що на відміну від аудиторних занять «face to face», кожен студент отримав можливість сприймати й обробляти навчальний матеріал у своєму темпі, відповідно до своїх індивідуальних психологічних особливостей.

Мета дослідження - визначення психолого-педагогічних особливостей дистанційного навчання іноземної мови у зВО. Головне завдання: дослідити психолого-педагогічні особливості дистанційного навчання іноземної мови у вищому навчальному закладі, визначити фрактори, які підвищують успішність іншомовного дистанційного навчання.

Методи дослідження. Під час дослідження ми застосовували такі методи: аналіз, систематизація та узагальнення психолого-педагогічної літератури із проблем дослідження; теоретичне моделювання; спостереження.

Результати і дискусії. На основі аналізу закордонної і вітчизняної психолого-педагогічної літератури можна виділити такі переваги застосування дистанційних освітніх технологій порівняно із традиційними методами навчання іноземної мови у вищих навчальних закладах:

1) analytics (аналітика). Застосовуючи електронні освітні технології під час викладання іноземної мови, виникає можливість отримати детальну інформацію про процес навчання (особливості поведінки студентів у віртуальному середовищі, сам процес навчання, оцінювання результатів навчання і встановлення зворотного зв'язку [5, с. 65-77];

2) free access (вільний доступ). Інтернет надає доступ до будь-якого електронного освітнього ресурсу іноземною мовою із будь-якого місця світу і у будь-який час доби;
3) adaptivity (адаптивність). У викладачів іноземної мови з'являється можливість змінювати і підлаштовувати електронні освітні ресурси під студентів, що дозволяє зробити процес навчання іноземної мови особистісно орієнтованим і результативнішим;

4) assessment (оцінювання). Дистанційні технології надають можливість зробити процес оцінювання фрормування компетенцій студентів безперервним і тривалим;

5) agility (гнучкість). Інформаційні технології дозволяють швидше перебудовувати навчальні плани і розширювати їх за необхідністю, а також забезпечують комунікацію викладачів і студентів різноманітними засобами [2, с. 105-110].

Успішність викладання іноземної мови на відстані залежить від таких компонентів:

- ефрективності взаємодії викладача і студента незалежно від того, на якій відстані вони знаходяться один від одного;

- які педагогічні технології використовуються у вищезазначеному процесі;

- ефективності розроблених методичних іншомовних матеріалів та засобів їх презентації;

- наявності і результативності зворотного зв'язку. Окрім ефрективної організації навчання і методичної якості навчальних матеріалів, що використовуються у дистанційному курсі, велике значення має вивчення фракторів, які підвищують успішність навчання будь-якої групи та окремого студента 3 урахуванням психологічних особливостей студентів, насамперед когнітивних стилів. Когнітивні стилі процесу пізнання об'єктивно є основою успішного опановування тією чи іншою галуззю знань. Урахування особливостей когнітивних стилів студентів під час засвоєння іноземної мови передбачає (разом із іншими компонентами) використання індивідуалізованих методів, засобів і технологій дистанційного навчання. Наприклад, студенти із візуальним типом сприйняття інфрормації під час дистанційного навчання потребують більше різноманітних наочних засобів (картинок, відеоматеріалів); аудіалістів потрібно забезпечити логічними схемами і навчальними матеріалами, які вони зможуть сприймати на слух. Студентам кінестичного типу сприйняття інорормації доцільно пропонувати інтерактивні завдання, тобто той матеріал, який вони зможуть швидко застосувати на практиці.

Іншомовне дистанційне навчання передбачає насампередінтерактивнувзаємодію викладачаістудента. Поняття «інтерактивна взаємодія»активно використовується як у вітчизняній, так і у закордонній педагогічній літературі. Насамперед інтерактивну взаємодію визначають як діалог користувача із програмою, тобто обмін текстовими командами (запитами) і відповідями (запрошеннями). За наявності можливості ставити запитання у довільній фрормі, використовуючи «ключове» слово, у фрормі 
3 обмеженим набором символів забезпечується можливість вибору варіантів змісту навчального матеріалу та режиму роботи. Чим більше існує можливостей керувати програмою і чим активніше студент бере участь у діалозі, тим вище інтерактивність. Інтерактивна взаємодія передбачає діалог будь-яких суб'єктів один із одним із використанням доступних їм засобів та методів. Водночас передбачається активна участь у діалозі обох сторін обмін питаннями і відповідями, управління перебігом діалогу, контроль за виконанням прийнятих рішень тощо. Під час викладання дистанційного курсу суб'єктами інтерактивної взаємодії виступають викладачі і студенти, а засобами здійснення подібної взаємодії - електронна пошта, телеконореренції, діалоги в онлайн-режимі тощо.

Під час очного навчання іноземної мови викладач може скорегувати хід заняття, якщо у студентів виникають труднощі під час виконання завдання, приділити опрацюванню теми більше часу або запропонувати додаткове домашнє завдання із відпрацювання теми. За дистанційного навчання поточний контроль виконання завдань утруднений, коригування ходу заняття зазвичай неможливе. У цьому випадку доцільно проводити окремі заняття для подолання труднощів: це можуть бути синхронні очні або онлайн-заняття, але ефективність відстроченого опрацювання труднощів $€$ нижчою. На очних заняттях відповіді на запитання можуть надаватись у поточному режимі, а динаміка взаємодії педагога зі студентом буде значно вищою. Однак деякі дослідники відзначають, що зниження контактної роботи із викладачем іноземної мови у низці випадків може зіграти і позитивну роль, оскільки у студента зникає сором і невпевненість, яка проявляється за безпосереднього контакту. Водночас дослідники не заперечують можливість використання очних зустрічей із викладачем для вирішення низки складних питань [1, с. 131-134].

Слід відзначити, що дистанційна форма навчання іноземної мови ускладнює процес відпрацювання мовленнєвих навичок: розмовної і писемної іноземної мови. Якщо писемна мова вимагає перевірки викладачем, то фрормування розмовних навичок - безпосередньої участі у навчальній бесіді або її безпосереднього спостереження, наприклад, задля запобігання неправильному запам'ятовуванню мовленнєвих зворотів. Розвиток навичок розмовної мови вимагає присутності викладача, у такому випадку заняття в онлайн-групі стають складними, а індивідуальний супровід $€$ витратним за часом.

Дистанційні освітні технології припускають розроблення індивідуальних навчальних програм, які враховують специфіку дистанційного навчання іноземної мови. Традиційно у вищій школі відбувається поділ на підгрупи залежно від рівня знання мови, наприклад, за підсумками «вхідного» контролю. Але зазвичай поділ на групи відбувається нерівномірно, навіть якщо перерозподіл триває у межах усього поточного набору, а не одного напряму підготовки. У контексті дистанційного навчання стає можливим створення курсів для кількох рівнів на одному потоці. У такому випадку студент вивчатиме іноземну мову у коморортному режимі, із рівнем складності, який відповідатиме його початковій підготовці.

Однією 3 індивідуальних навчальних програм, які враховують специфріку дистанційного навчання, на думку Н.В. Матецького, є навчальне комп'ютерне завдання, що розглядається як один із основних засобів ефективної організації самостійної роботи студента, що, у свою чергу, дозволяє забезпечити інтерактивність його навчання іноземній мові [8].

Відмінними особливостями навчання на основі навчальних комп'ютерних завдань виступають такі:

- студентська активність;

- безперервна підтримка своїх дій на основі самоконтролю;

- навчально-пізнавальна діяльність, яка проходить в індивідуалізованому темпі;

- гнучкий контроль навчально-пізнавальної діяльності учнів, який поступово переходить у самоврядування;

- застосування рефлексивного підходу;

- максимальна індивідуалізація просування у навчальному процесі.

У педагогічному аспекті навчальні комп'ютерні завдання під час викладання іноземної мови насамперед розв'язують такі проблеми: фрормування у студентів потреби самонавчатися; розвиток творчих якостей студентів; фрормування пізнавальної самостійності. Вони виявляються ключовим компонентом організаційно-дидактичної структури дистанційного курсу іноземної мови, оскільки допомагають інтенсифікувати самостійну пізнавальну діяльність студентів. Дидактична структура навчальних комп'ютерних завдань містить дидактичну мету, актуалізацію знань і засобів дій, формування нових знань і засобів дій, контроль результатів пізнавальної діяльності, використання нових знань на практиці, комплекс інфрормаційної підтримки та допомоги.

Під час підготовки і моделювання навчального комп'ютерного завдання доцільно використовувати таку технологію: визначення конкретного тематичного розділу; структурування іншомовного навчального матеріалу, моделювання структурнологічної схеми розділу, що вивчається; виділення найбільш значущих навчальних компонентів досліджуваної теми.

Етапами технології моделювання навчального комп'ютерного завдання під час дистанційного навчання іноземної мови $€$ такі:

1) визначити мету завдання, де указати, який саме навчальний елемент підлягає вивченню; 
встановити потрібний для вивчення обсяг знань про навчальні елементи та перелік компонентів знань із зазначеного навчального елементу;

2) кваліфікувати базові знання, потрібні для використання їх як опорних під час засвоєння нового навчального матеріалу;

3) спираючись на базові знання, створити навчальний компонент навчального комп'ютерного завдання, що має конкретний характер (виконання тестів, вправ, аналіз речень, складання плану переказу тощо);

4) спланувати можливі дії студентів із виконання пізнавальних компонентів;

5) відібрати передбачувані шляхи досягнення мети (моделювання, імітація, демонстрація, відео, аудіо, схема);

6) створити пізнавальний компонент навчального комп'ютерного завдання, структурувати поняття, побудувати модель, змоделювати алгоритм дій;

7) спланувати організацію зворотного зв'язку: перевірку та аналіз результатів виконання пізнавального компонента завдання;

8) розробити системи проміжного і кінцевого контролю знань та засобів діяльності у фрормі тестів, вправ тощо;

9) підготувати комплекс інформаційної підтримки та допомоги (довідкову і спеціальну інформацію про виконання навчального комп'ютерного завдання), який міститиме короткі відомості про курс іноземної мови, що викладається дистанційно (наприклад, граматичний матеріал, стійкі мовленнєві кліше), приклади виконання навчального комп'ютерного завдання (застосування знань за зразком), короткі вказівки до виконання завдання (підказки).

Програма дистанційного навчання іноземної мови має модульний характер; набір модулів може відрізнятися за напрямом підготовки та/або рівнем початкових знань або від бажаного рівня «занурення» у предмет. Ступінь «занурення» залежатиме не тільки від заданих програмою передбачуваних результатів навчання, але і від цілей, які перед собою ставить студент. Стає можливою різнорівнева підготовка у межах заявлених модулів. Відзначимо, що у цьому випадку модуль буде закінченим елементом процесу навчання (від вступного заняття до підсумкового контролю засвоєння матеріалу), він повинен закріплювати і підвищувати рівень підготовки відповідно до запланованих результатів. Тривалість модулів залежно від теми або блоку тем, які вони розкривають, може бути різною. Модульний підхід до побудови курсу може мати загальні модулі для різних напрямів підготовки (наприклад, початкові граматичні теми), а також вузькоспеціалізовані, поглиблені. У такому випадку поглиблене вивчення предмета $€$ можливим за збільшення годин самостійної роботи студента і за збереження або незначного збільшення годин контактної роботи із викладачем. Подібне управління своїми кінцевими цілями під час вивчення дисципліни «Іноземна мова» (у межах мінімуму, визначеного освітнім стандартом) дозволяє студенту вибудовувати індивідуальну освітню траєкторію із подальшим її розвитком у профресійну траєкторію.

Дистанційне навчання розглядається передусім як готовність і мотивація студентів до самостійної роботи. Студент, отримуючи від викладача потрібний обсяг навчальних матеріалів, формує здатність до самоорганізації і самоконтролю. Використання уніфікованих навчальних блоків дозволяє забезпечувати повноцінну взаємодію викладача і студента. Для студента модульна подача матеріалу дозволяє ефективніше отримувати потрібний обсяг знань, умінь і навичок, а для викладача - створює можливість забезпечити повномірний контроль якості і кількості засвоєної навчальної інфрормації. Окрім того, самостійні блоки навчальної інорормації сприяють активізації розумової діяльності, оскільки для того, щоб аргументовано відповісти на запитання викладача, студенту слід не просто прочитати запропонований навчальний матеріал і перекласти його, але і розгорнуто відповісти на запитання викладача. На цьому етапі викладач може повно оцінити рівень засвоєного матеріалу та визначити якість самостійної роботи студента [3, с. 184-190].

Сучасне завдання процесу вищої освіти - формування вільної творчої особистості. Отже, під час навчального процесу студент стає не об'єктом, а суб'єктом пізнавальної діяльності, що означає пріоритет самостійних видів діяльності, необхідність активності студентів із пошуку, обробки, осмислення потрібної їм інфрормації. Така установка зумовлює передусім такі дії:

- перегляд позиції викладача як оповідача і практично єдиного джерела інфрормації для студентів;

- необхідність своєчасного контролю викладачем виконання самостійної роботи студентів, який може здійснюватись у вигляді проміжних систем завдань, за результатами котрих студент або продовжує навчання, або опрацьовує не досить вивчений матеріал;

- засвоєння гнучких фрорм організації занять, таких як робота у групах, робота над проєктами, які неможливо повноцінно проводити під час аудиторного заняття.

Низка дослідників уважає, що підготовка студентів до самостійної роботи засобами інфрормаційнокомунікаційних технологій під час вивчення іноземної мови сприяє глибшому вивченню обраної теми, аналізу і систематизації отриманого матеріалу, планування й опису результатів своєї діяльності. Окрім того, визначаючи ефективність дистанційного навчання іноземної мови, вони обґрунтували його потенціал для саморозвитку особистості і відповідність принципам особистісно орієнтованого підходу у контексті освітнього процесу. Впровадження дистанційних освітніх технологій дозволяє створити 
педагогічний супровід самостійної роботи студентів із іноземної мови, впровадити інтернет-тестування як вид самостійної роботи студента у чинну практику викладання іноземної мови у вищій школі, розробити електронні освітні ресурси ігрового характеру для самостійного вивчення іноземної мови, запропонувати алгоритм самостійної роботи з інтернет-ресурсами з метою вдосконалення навичок писемного мовлення іноземною мовою.

Висновки. Нині система дистанційного навчання інтенсивно розвивається і вдосконалюється. Сорери застосування дистанційного навчання іноземним мовам у вищих навчальних закладах розширюються завдяки його профрільній організації (наприклад, у вигляді курсів за вибором), інтеграції фрормальної і неформальної освіти, підвищенню кваліфрікації викладачів. Окрім того, слід відзначити, що дистанційне навчання сприяє втіленню сучасної освітньої парадигми, невід'ємними компонентами якої $€$ особистісно орієнтоване навчання, індивідуалізація і диференціація навчальної діяльності, можливість автономного навчання, самоосвіта і саморозвиток студентів. Дистанційне навчання також $€$ мотивуючим фрактором вивчення іноземних мов, оскільки сприяє не тільки фрормуванню загальнокультурних і профресійних компетенцій студентів, але й іншомовної комунікативної компетенції.

Усі ці чинники зумовлюють необхідність розроблення сучасних програм розвитку лінгвістичної освіти, а також моделі дистанційного навчання, зокрема 3 іноземних мов, з урахуванням педаго- гічних позицій і соціокультурних, культурологічних, психологічних особливостей студентів.

Перспективу подальшого дослідження ми вбачаємо у розробленні комплексної програми вивчення психолого-педагогічних основ дистанційного навчання іноземної мови, яка враховує, з одного боку, когнітивні й особистісні особливості, потрібні для навчання за допомогою дистанційних технологій, а з іншого боку, вплив дистанційних технологій на когнітивний та особистісний розвиток студентів.

\section{БІБЛІОГРАФІЧНИЙ СПИСОК:}

1. Бороненко Т.А., Кайсина А. В., Федотова В.С. Диалог в дистанционном обучении. Высшее образование в России. 2017. № 8-9. С. 131-134.

2. Ивачев П.В. Модульная организация обучения в формате информационного взаимодействия. Специальное образование. 2011. № 3. С. 105-110.

3. Кравченко О.В. Внедрение компьютерных технологий в изучение иностранных языков. Проблеми інженерно-педагогічної освіти : зб. наук. пр. Укр. інж.-пед. акад. 2004. № 6. С. 184-190.

4. Матецкий Н.В. Компьютерные задания как средство организации эвристической учебной деятельности учащихся в дистанционном обучении : авторефр. дис. ... канд. пед. наук. Москва, 2001. 19 с.

5. Митрофанова К.А. Электронные технологии учета учебных достижений студентов-медиков. Высшее образование в России. 2014. № 4. С. 65-77.

6. Cook D.A., Triola M.M. What is the role of e-learning? Looking past the hype. Medical Education. 2014. Vol. 48. P. 930-937.

7. Peters O. Distance Education in Transition. New Trends and Challenges. Oldenburg. 2004. P. 37-47. 